least; the third longest, but the second almost equal; the fourth and fifth very little shorter; the first much longer than the seventh; tail emarginate. Upper parts dull ash-grey, shaded with brown posteriorly; a concealed patch of bright vermilion on the top of the head; wing-coverts, quills and tail chocolate-brown, margined with brownish-white; lower parts anteriorly ash-grey, behind greyish-white, tinged with yellow; lower wing-coverts pale sulphuryellow. Female similar.

Male, $8 \frac{7}{8}, 14 \frac{3}{8}$.

\title{
Agati Grandiflora.
}

This leguminous plant is one of the handsomest productions of Key-West, where I found it in full flower in the month of May. It reaches the height of twenty feet or more, and has a rather slender but elegant stem, of which the wood is as brittle as that of our common acacias. The pods are eight or nine inches in length, and of the size of a Swan's quill; the seeds, which are dark brown when ripe, glossy and globular, lie at regular intervals. The deep green of the long pendulous leaves, and the bright red of the large papilionaceous flowers, form a beautiful contrast. Many of these trees were planted near the house of my friend Dr. BENJAMin STrobel, under whose hospitable roof the twig was drawn. I saw no plants of the species on any other Key.

\section{THE TYRANT FLYCATCHER.-KING BIRD.}

\section{+Muscicapa tyrannus, Linn.}

\section{PLate LVI.-Male and Female.}

The Tyrant Flycatcher, or, as it is commonly named, the Field Martin, or King Bird, is one of the most interesting visiters of the United States, where it is to be found during spring and summer, and where, were its good qualities appreciated as they deserve to be, it would remain unmolested. But man being generally disposed to consider in his subjects a single fault sufficient to obliterate the remembrance of a thousand good qualities, even when the latter are beneficial to his interest, and tend to promote his comfort, persecutes the King Bird without mercy, and extends his enmity to its whole progeny. This mortal hatred is occasioned by a propensity which the Tyrant Flycatcher now and then shews to eat a honey-bee, which the farmer looks upon as exclusively his own property. 


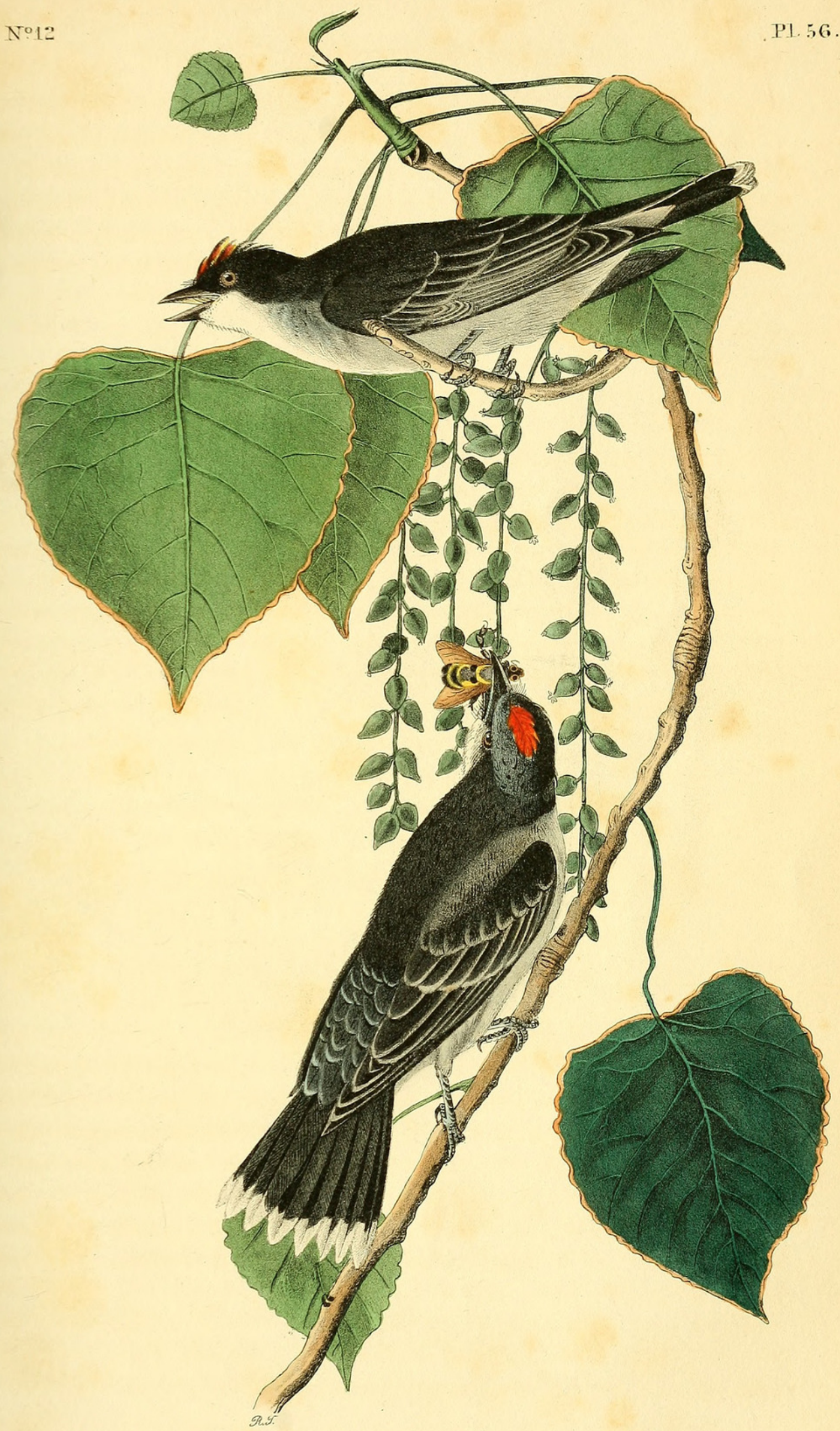

Sysant. Thycatcher or. Ming OBirde. Cottontwood Sofuetus candicans. 

The Field Martin arrives in Louisiana, from the south, about the middle of March. Many individuals remain until the middle of September, but the greater number proceed gradually northwards, and are dispersed over every portion of the United States. For a few days after its arrival, it seems fatigued and doleful, and remains perfectly silent. But no sooner has it recovered its naturally lively spirits, than its sharp tremulous cry is heard over the fields, and along the skirts of all our woods. It seldom ențers the forests, but is fond of orchards, large fields of clover, the neighbourhood of rivers, and the gardens close to the houses of the planters. In this last situation its habits are best observed.

Its flight has now assumed a different manner. The love-season is at hand. The male and female are seen moving about through the air, with a continued quivering motion of their wings, at a height of twenty or thirty yards above the ground, uttering a continual, tremulous, loud shriek. The male follows in the wake of the female, and both seem panting for a suitable place in which to form their nest. Meanwhile, they watch the motions of different insects, deviate a little from the course of their playful rounds, and with a sweeping dart secure and swallow the prey in an instant. Probably the next sees them perched on the twig of a tree, close together, and answering the calls of nature.

The choice of a place being settled by the happy pair, they procure small dry twigs from the ground, and rising to a horizontal branch, arrange them as the foundation of their cherished home. Flakes of cotton, wool or tow, and other substances of a similar nature, are then placed in thick and regular layers, giving great bulk and consistence to the fabric, which is finally lined with fibrous roots and horse-hair. The female then deposits her eggs, which are from four to six in number, broadly ovate, reddish-white, or blush colour, irregularly spotted with brown. No sooner has incubation commenced, than the male, full of ardour, evinces the most daring courage, and gallantly drives off every intruder. Perched on a twig not far from his beloved mate, in order to protect and defend her, he seems to direct every thought and action to these objects. His snow-white breast expands with the warmest feelings; the feathers of his head are raised and spread, the bright orange spot laid open to the rays of the sun; he stands firm on his feet, and his vigilant eye glances over the wide field of vision around him. Should he espy a Crow, a Vulture, a Martin, or an Eagle, in the neighbourhood or at a distance, he spreads his wings to the air, and pressing towards the dangerous foe, approaches him, and commences his attack with fury. He mounts above the enemy, sounds the charge, and repeatedly plunging upon the very back of his more powerful antagonist, essays to secure a hold. In this manner, harassing his less active foe with continued blows of his bill, he follows him

VOL. I. 
probably for a mile, when, satisfied that he has done his duty, he gives his wings their usual quivering motion, and returns exulting and elated to his nest, trilling his notes all the while.

Few Hawks will venture to approach the farm-yard while the King Bird is near. Even the cat in a great measure remains at home; and, should she appear, the little warrior, fearless as the boldest Eagle, plunges towards her, with such rapid and violent motions, and so perplexes her with attempts to peck on all sides, that grimalkin, ashamed of herself, returns discomfited to the house.

The many eggs of the poultry which he saves from the plundering Crow, the many chickens that are reared under his protection, safe from the clutches of the prowling Hawks, the vast number of insects which he devours, and which would otherwise torment the cattle and horses, are benefits conferred by him, more than sufficient to balance the few raspberries and figs which he eats, and calculated to insure for him the favour and protection of man.

The King Bird fears none of his aërial enemies save the Martin; and although the latter frequently aids him in protecting his nest, and watching over the farm-yard, it sometimes attacks him with such animosity as to force him to retreat, the flight of the Martin being so superior to that of the King Bird in quickness and power, as to enable it to elude the blows which the superior strength of the latter might render fatal. I knew an instance in which some Martins, that had been sole proprietors of a farm-yard for several seasons, shewed so strong an antipathy to a pair of King Birds, which had chanced to build their nest on a tree within a few yards of the house, that, no sooner had the female begun to sit on her eggs, than the Martin attacked the male with unremitting violence for several days, and, notwithstanding his courage and superior strength, repeatedly felled him to the ground, until he at length died of fatigue, when the female was beaten off in a state of despair, and forced to seek a new protector.

The King Bird is often seen passing on the wing over a field of clover, diving down to the very blossoms, and reascending in graceful undulations, snapping his bill, and securing various sorts of insects, now and then varying his mode of chase in curious zigzag lines, shooting to the right and left, up and down, as if the object which he is pursuing were manœuvring for the purpose of eluding him.

About the month of August, this species becomes comparatively mute, and resorts to the old abandoned fields and meadows. There, perched on a fencestake or a tall mullein stalk, he glances his eye in various directions, watching the passing insects, after which he darts with a more direct motion than in spring. Having secured one, he returns to the same or another stalk, beats the insect, and then swallows it. He frequently flies high over the 
large rivers and lakes, sailing and dashing about in pursuit of insects. Again, gliding down towards the water, he drinks in the manner of various species of Swallow. When the weather is very warm, he plunges repeatedly into the water, alights after each plunge on the low branch of a tree close by, shakes off the water and plumes himself, when, perceiving some individuals of his tribe passing high over head, he ascends to overtake them, and bidding adieu to the country, proceeds towards a warmer region.

The King Bird leaves the Middle States earlier than most other species. While migrating southwards, at the approach of winter, it flies with a strong and continued motion, flapping its wings six or seven times pretty rapidly, and sailing for a few yards without any undulations, at every cessation of the flappings. On the first days of September, I have several times observed them passing in this manner, in detached parties of twenty or thirty, perfectly silent, and so resembling the Turdus migratorius in their mode of flight, as to induce the looker-on to suppose them of that species, until he recognises them by their inferior size. Their flight is continued through the night, and by the 1st of October none are to be found in the Middle States. The young acquire the full colouring of their plumage before they leave us for the south.

The flesh of this bird is delicate and savoury. Many are shot along the Mississippi, not because these birds eat bees, but because the French of Louisiana are fond of bee-eaters. I have seen some of these birds that had the shafts of the tail-feathers reaching a quarter of an inch beyond the end of the webs.

This bold Flyeatcher is not satisfied with ranging throughout the United States, but extends its migrations across the continent to the Columbia River, and, according to Dr. Richardson, northward as far as the 57th parallel, where it breeds, arriving in May, and departing in the beginning of September. I have found it breeding in the Texas, on the one hand, in Labrador on the other, and in all intervening districts, excepting the Florida Keys, where it is represented by the Pipiry Flycatcher. I have never seen it dive after fish, or even after aquatic insects, although, as I have already mentioned, it throws itself into the water for the purpose of bathing; nor have remains of fishes been found in its stomach or gullet. Like all Flycatchers, it disgorges the harder parts of insects.

How wonderful is it that this bird should be found breeding over so vast an extent of country, and yet retire southward of the Texas, to spend a very short part of the winter! Some, however, remain then in the southern portions of the Floridas. The eggs measure rather more than an inch in length, and six and a half eighths in breadth; they are broadly rounded at the larger end, the other being suddenly brought to a sharpish conical point. 
This bird has the mouth wide, the palate flat, with two longitudinal ridges, its anterior part horny, and concave, with a median and two slight lateral prominent lines; the posterior aperture of the nares oblongo-linear, papillate, $4 \frac{1}{2}$ twelfths long. The tongue is six-twelfths long, triangular, very thin, sagittate and papillate at the base, flat above, pointed, but a little slit, and with the edges slightly lacerated. The œsophagus is $2 \frac{1}{2}$ inches long, without dilatation, of the uniform width of 3 twelfths, and extremely thin; the proventriculus $3 \frac{1}{2}$ twelfths across. The stomach is rather large, broadly elliptical, considerably compressed; its lateral muscles strong, the lower thin, its length 10 twelfths, its breadth 8 twelfths, its tendons $4 \frac{1}{2}$ twelfths in breadth; the epithelium thin, tough, longitudinally rugous, reddish-brown. The stomach filled with remains of insects. The intestine is short and wide, 7 inches long, its width at the upper part 4 twelfths, at the lower 2 twelfths. The cœca are 2 twelfths long, $\frac{1}{2}$ twelfth in breadth, and placed at an inch and a half from the extremity. The rectum gradually dilates into the cloaca, which is 6 twelfths in width.

The trachea is 2 inches 2 twelfths long, considerably flattened, $2 \frac{1}{2}$ twelfths broad at the upper part, gradually contracting to $1 \frac{1}{4}$ twelfths; its rings 56 , firm, with 2 dimidiate rings. It is remarkable that in this and the other Flycatchers, there is no bone of divarication, or ring divided by a partition; but two of the rings are slit behind, and the last two both behind and before. Bronchial rings about 15 . The lateral muscles are slender, but at the lower part expand so as to cover the front of the trachea, and running down, terminate on the dimidiate rings, so that on each side of the inferior larynx there is a short thick mass of muscular fibres, which are scarcely capable of being divided into distinct portions, although three pairs may be in some degree traced, an anterior, a middle, and a posterior. These muscles are similarly formed in all the other birds of this family the Muscicapinx, described in this work.

Lanius Tyrannus, Linn. Syst. Nat., vol. i. p. 136.

Tyrant Flycatcher, Muscicapa tyrannus, Wils. Amer. Orn., vol. i. p. 66.

Muscicapa Tyrannus, Bonap. Syn., p. 66.

King-bird or Tyrant Flycatcher, Muscicapa tyrannus, Nutt. Man., vol, i. p. 265.

Tyrant Flycatcher, Muscicapa tyrannus, Aud. Orn. Biog., vol. i. p. 403; vol. v. p. 420.

The outer two primaries attenuated at the end, the second longest, the first longer than the third; tail even. Upper parts dark bluish-grey; the head greyish-black, with a bright vermilion patch margined with yellow; quills, coverts, and tail feathers brownish-black, the former margined with dull white, the latter largely tipped with white; lower parts greyish-white; 
the breast pale grey. Female duller; the upper parts tinged with brown; the lower more dusky.

Male, $8 \frac{1}{2}, 14 \frac{1}{2}$.

North America generally. Migratory. A few winter in the south of Florida.

\title{
The Cotton-wood.
}

Populus candicans, Willd., Sp. Pl., vol. iv. p. 806. Pursh., Fl. Amer., vol, ii. p. 618. Mich., Arbr. Forest. de l'Amér. Sept., vol. iii. pl. 13.-Diecia octandria, Linn.Amentacee, Juss.

This species of Poplar is distinguished by its broadly cordate, acuminate, unequally and obtusely serrated venous leaves, hairy petioles, resinous buds, and round twigs. The leaves are dark green above, whitish beneath. The resinous substance with which the buds are covered has an agreeable smell. The bark is smooth, of a greenish tint.

\section{THE GREAT CRESTED FLYCATCHER.}

\author{
+ Muscicapa crinita, Linn.
}

\section{PLATE LVII.-MALE.}

How often whilst gazing on the nest of a bird, admiring the beauty of its structure, or wondering at the skill displayed in securing it from danger, have I been led to question myself why there is often so much difference in the conformation and materials of the nests of even the same species, in different latitudes or localities. How often, too, while admiring the bird itself, have $I$ in vain tried to discover the causes why more mental and corporeal hardihood should have been granted to certain individuals, which although small and seemingly more delicate than others, are wont to force their way, and that an early season, quite across the whole extent of the United States; while some, of greater bodily magnitude, equal powers of flight, and similar courage, never reach so far, in fact merely enter our country or confine their journeys to half the distance to which the others reach. The diminutive Ruby-throated Humming-bird, the delicate Winter Wren, and many warblers, all birds of comparatively short flight, are seen to push their way from the West India Islands, or the table-lands of Mexico and South America, VOL. I. 


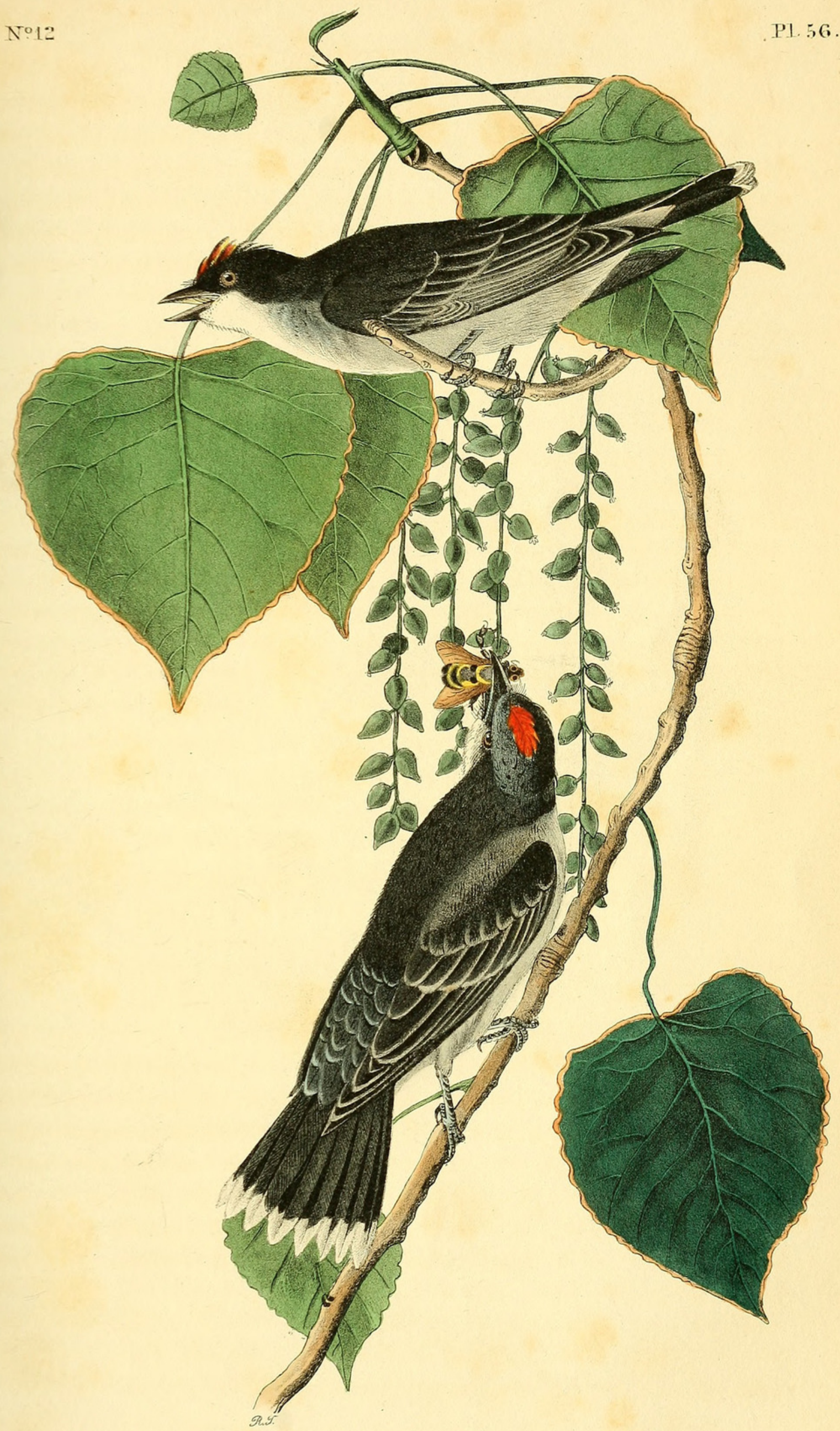

Sysant. Thycatcher or. Ming OBirde. Cottontwood Sofuetus candicans. 


\section{$2 \mathrm{BHL}$ Biodiversity Heritage Library}

Audubon, John James. 1840. "The Tyrant Flycatcher, Muscicapa tyrannus, Linn. [PI. 56]." The birds of America : from drawings made in the United States and their territories 1, 204-209. https://doi.org/10.5962/p.319169.

View This Item Online: https://www.biodiversitylibrary.org/item/124833

DOI: https://doi.org/10.5962/p.319169

Permalink: https://www.biodiversitylibrary.org/partpdf/319169

\section{Holding Institution}

Smithsonian Libraries

\section{Sponsored by}

Biodiversity Heritage Library

\section{Copyright \& Reuse}

Copyright Status: NOT_IN_COPYRIGHT

This document was created from content at the Biodiversity Heritage Library, the world's largest open access digital library for biodiversity literature and archives. Visit BHL at https://www.biodiversitylibrary.org. 